\title{
Geographic variation in body and ovipositor sizes in the leaf beetle Plateumaris constricticollis (Coleoptera: Chrysomelidae) and its association with climatic conditions and host plants
}

\author{
TeiJI SOTA ${ }^{1}$, Masakazu HAYASHI $^{2}$ and Tsuyoshi YAGI ${ }^{3}$ \\ ${ }^{1}$ Department of Zoology, Graduate School of Science, Kyoto University, Sakyo, Kyoto, 606-8502, Japan; \\ e-mail: sota@terra.zool.kyoto-u.ac.jp \\ ${ }^{2}$ Hoshizaki Green Foundation, Izumo, Shimane, 691-0076, Japan \\ ${ }^{3}$ The Museum of Nature and Human Activities, Hyogo, Sanda, Hyogo, 669-1546, Japan
}

Keywords. Chrysomelidae, life history, molecular phylogeny, wetland, 28S rRNA gene

\begin{abstract}
Plateumaris constricticollis is a donaciine leaf beetle endemic to Japan, which lives in wetlands and uses Cyperaceae and Poaceae as larval hosts. We analyzed geographic variation in body size and ovipositor dimensions in three subspecies (constricticollis, babai, and toyamensis) in different climatic conditions and on different host plants. In addition, the genetic differentiation among subspecies was assessed using nuclear 28S rRNA gene sequences. The body size of subspecies toyamensis is smaller than that of the other subspecies; mean body size tended to increase towards the northeast. Ovipositor length and width are smaller in subspecies toyamensis than in the other subspecies. Although these dimensions depend on body size, ovipositor length still differed significantly between toyamensis and constricticollis-babai after the effect of body size was removed. Multiple regression analyses revealed that body size and ovipositor size are significantly correlated with the depth of snow, but not temperature or rainfall; sizes were larger in places where the snowfall was greatest. Haplotypes of the 28S rRNA gene sequence were not shared among the subspecies. Subspecies constricticollis and babai each had a unique haplotype, whereas subspecies toyamensis had four haplotypes, indicating differentiation among local populations within toyamensis. The evolution of body and ovipositor size in relation to habitat conditions and host plants is discussed.
\end{abstract}

\section{INTRODUCTION}

Geographic variation in insect body size reflects the differential adaptation of local populations to local environmental conditions such as climatic factors, food availability, and the presence of related species (Masaki, 1967, 1978; Roff, 1980; Mousseau \& Roff, 1989; Blanckenhorn \& Fairbairn, 1995; Sota et al., 2000a, b). As body parts are particularly important in the adaptation to habitat and food conditions, the ovipositor and associated structures also show marked geographic variation in response to abiotic conditions (Masaki, 1979, 1986; Bradford et al., 1993; Mousseau \& Roff, 1995) and host plant morphology (e.g., Toju \& Sota, 2006a, b). Analyses of geographic variation in body size and the size of other functional parts are important for understanding locally variable adaptations, which produce morphological diversity within insect species and potentially lead to speciation.

Here, we analyze the geographic variation in body and ovipositor sizes of a wetland leaf beetle, Plateumaris constricticollis (Coleoptera, Chrysomelidae), a Donaciinae species endemic to the Japanese archipelago the larvae of which feed on the roots of monocotyledonus plants. Fossils of this species are known from the late Pliocene, along with another endemic species $P$. akiensis, although few extant species occur in late Pliocene and early Pleistocene deposits (Hayashi, 2002b, 2004; Hayashi \& Shiyake, 2002). Thus, P. constricticollis represents one of the few ancient insect species persisting since the late Pliocene. Whereas $P$. akiensis is confined to a small area in western Honshu, $P$. constricticollis is distributed widely from western Honshu to Hokkaido and is polytypic with three subspecies (Hayashi, 2004; Hayashi \& Shiyake, 2004) characterized by external and internal (ovipositor) characters. The two northern subspecies, constricticollis and babai, have equally long ovipositors with an acutely angled apex (Fig. 1), but differ in body coloration. The southwestern subspecies, toyamensis, has a shorter ovipositor with a right-angled apex and a smaller body than the other two subspecies (Fig. 1). The different morphological characters of the $P$. constricticollis subspecies may reflect local adaptations to different host plants or climatic conditions; the length of its ovipositor appears to match the stem thickness of its host plants (T. Yagi, unpubl. observ.), and larger body may have resulted from an adaptation to a climate with higher snowfall (Ego et al., 1988; Tominaga, 1988).

Here, we describe the variation in body and ovipositor size among local populations and analyze the effects of environmental variables on morphological variation. Further, we examine the relationship between morphological (subspecies) differentiation and genetic differentiation using partial sequence data from the nuclear $28 \mathrm{~S}$ rRNA gene.

\section{MATERIAL AND METHODS}

\section{Morphological analysis}

A total of 235 female beetles were collected from 20 sites for morphological analysis (Table 1, Fig. 1). To measure pronotum 
TABLE 1. Sampling localities and number of specimens of Plateumaris constricticollis used in the morphological analysis of female beetles and molecular phylogenetic analysis.

\begin{tabular}{|c|c|c|c|c|c|}
\hline \multirow{2}{*}{ Locality } & \multirow{2}{*}{ Latitude, ${ }^{\circ} \mathrm{N}$} & \multirow{2}{*}{ Longitude, ${ }^{\circ} \mathrm{E}$} & \multirow{2}{*}{ Host plants available ${ }^{a}$} & \multicolumn{2}{|c|}{ Sample size } \\
\hline & & & & Morphology & DNA \\
\hline \multicolumn{6}{|l|}{ Subspecies constricticollis } \\
\hline 1. Toyotomi, Hokkaido & $45^{\circ} 13^{\prime} 00^{\prime \prime}$ & $141^{\circ} 41^{\prime} 59^{\prime \prime}$ & $\mathrm{C}$ & 8 & 1 \\
\hline 2. Kuromatsunai, Hokkaido & $42^{\circ} 38^{\prime} 14^{\prime \prime}$ & $140^{\circ} 20^{\prime} 18^{\prime \prime}$ & $\mathrm{C}, \mathrm{P}$ & 14 & 1 \\
\hline 3. Nanae, Hokkaido & $41^{\circ} 59^{\prime} 42^{\prime \prime}$ & $140^{\circ} 39^{\prime} 53^{\prime \prime}$ & $\mathrm{C}, \mathrm{P}$ & - & 1 \\
\hline 4. Ohma, Aomori & $41^{\circ} 32^{\prime} 42^{\prime \prime}$ & $140^{\circ} 54^{\prime} 44^{\prime \prime}$ & $?$ & 8 & 1 \\
\hline 5. Takizawa, Iwate & $39^{\circ} 47^{\prime} 01^{\prime \prime}$ & $141^{\circ} 01^{\prime} 49^{\prime \prime}$ & $?$ & 8 & - \\
\hline 6. Onoda, Miyagi & $38^{\circ} 30^{\prime} 07^{\prime \prime}$ & $140^{\circ} 39^{\prime} 25^{\prime \prime}$ & $\mathrm{C}, \mathrm{P}$ & 20 & 1 \\
\hline 7. Goshikinuma, Yamagata & $38^{\circ} 29^{\prime} 38^{\prime \prime}$ & $140^{\circ} 00^{\prime} 02^{\prime \prime}$ & $?$ & - & 1 \\
\hline 8. Sekikawa, Niigata & $38^{\circ} 03^{\prime} 42^{\prime \prime}$ & $139^{\circ} 37^{\prime} 25^{\prime \prime}$ & $\mathrm{P}$ & 3 & 1 \\
\hline 9. Oguni, Yamagata & $38^{\circ} 00^{\prime} 05^{\prime \prime}$ & $139^{\circ} 51^{\prime} 23^{\prime \prime}$ & $P$ & 8 & - \\
\hline \multicolumn{6}{|l|}{ Subspecies babai } \\
\hline 10. Shiobara, Fukushima & $37^{\circ} 37^{\prime} 5^{\prime \prime}$ & $140^{\circ} 00^{\prime} 27^{\prime \prime}$ & & 20 & 1 \\
\hline 11. Hanawa, Fukushima & $36^{\circ} 57^{\prime} 13^{\prime \prime}$ & $140^{\circ} 25^{\prime} 28^{\prime \prime}$ & $\mathrm{C}, \mathrm{P}$ & 5 & 1 \\
\hline 12. Fujihara, Tochigi & $36^{\circ} 54^{\prime} 53^{\prime \prime}$ & $139^{\circ} 44^{\prime} 10^{\prime \prime}$ & $\mathrm{C}, \mathrm{E}$ & 10 & 1 \\
\hline 13. Numata, Gunma & $36^{\circ} 46^{\prime} 31^{\prime \prime}$ & $139^{\circ} 04^{\prime} 13^{\prime \prime}$ & $\mathrm{C}, \mathrm{P}$ & 22 & 1 \\
\hline 14. Funabashi, Chiba & $35^{\circ} 43^{\prime} 33^{\prime \prime}$ & $140^{\circ} 02^{\prime} 20^{\prime \prime}$ & $\mathrm{C}$ & 6 & 1 \\
\hline 15. Shitada, Niigata & $37^{\circ} 26^{\prime} 38^{\prime \prime}$ & $139^{\circ} 07^{\prime} 42^{\prime \prime}$ & $\mathrm{C}, \mathrm{P}$ & - & 1 \\
\hline 16. Yamakoshi, Niigata & $37^{\circ} 20^{\prime} 09^{\prime \prime}$ & $138^{\circ} 54^{\prime} 27^{\prime \prime}$ & $\mathrm{P}$ & 6 & - \\
\hline 17. Tohkaichi, Niigata & $37^{\circ} 06^{\prime} 21^{\prime \prime}$ & $138^{\circ} 46^{\prime} 29^{\prime \prime}$ & $\mathrm{P}$ & 16 & - \\
\hline 18. Itoigawa, Niigata & $36^{\circ} 57^{\prime} 35^{\prime \prime}$ & $137^{\circ} 54^{\prime} 34^{\prime \prime}$ & $\mathrm{P}$ & - & 1 \\
\hline 19. Shinano, Nagano & $36^{\circ} 48^{\prime} 56^{\prime \prime}$ & $138^{\circ} 12^{\prime} 48^{\prime \prime}$ & $\mathrm{C}, \mathrm{P}$ & 20 & 1 \\
\hline \multicolumn{6}{|l|}{ Subspecies toyamensis } \\
\hline 20. Miyagawa, Gifu & $36^{\circ} 21^{\prime} 43^{\prime \prime}$ & $137^{\circ} 14^{\prime} 22^{\prime \prime}$ & $\mathrm{C}, \mathrm{P}$ & 20 & 1 \\
\hline 21. Tugu, Aichi & $35^{\circ} 11^{\prime} 15^{\prime \prime}$ & $137^{\circ} 35^{\prime} 28^{\prime \prime}$ & $\mathrm{C}$ & 9 & 1 \\
\hline 22. Ohkawachi, Hyogo & $35^{\circ} 09^{\prime} 10^{\prime \prime}$ & $134^{\circ} 41^{\prime} 24^{\prime \prime}$ & $\mathrm{E}$ & 20 & 1 \\
\hline 23. Kamisaibara, Okayama & $35^{\circ} 17^{\prime} 46^{\prime \prime}$ & $133^{\circ} 54^{\prime} 08^{\prime \prime}$ & $\mathrm{C}, \mathrm{P}$ & 5 & 1 \\
\hline 24. Tessei, Okayama & $34^{\circ} 55^{\prime} 00^{\prime \prime}$ & $133^{\circ} 21^{\prime} 06^{\prime \prime}$ & $\mathrm{C}, \mathrm{P}$ & 7 & 1 \\
\hline
\end{tabular}

${ }^{a} \mathrm{C}$ - Carex (Cyperaceae); E - Eleocharis (Cyperaceae); P - Phragmites (Poaceae).

width, right elytral length, and ovipositor length and width, a dorsal image of the whole body and dorsal and lateral images of the ovipositor were taken using a CCD camera mounted on a microscope. The software ImageJ 1.34s (National Institute of Health, USA) was used to determine the dimensions from the images (see Fig. 2). Ovipositor length was measured along the curved line from the apex to the base on the lateral image of the chitinized ovipositor. The maximum width on the dorsal image was used as ovipositor width.

In the statistical analysis, all millimeter dimensions were $\log _{10}$ transformed to ensure normality and homoscedasticity. All statistical analyses of the morphological data were performed using JMP 5.0.1J (SAS Institute Inc.). To reveal the climatic factors affecting body size variation, annual mean temperature, annual rainfall, and snowfall data from Mesh Climatic Data 2000 (Japan Meteorological Agency, 2002) were used in a multiple regressions with stepwise model selection. For snowfall, the maximum depth of snow in February, among others (maximum depth of snow in December-March, and the average and maximum of these monthly data), because the $F$-values were highest for the effect of this variable on body and ovipositor sizes. In the multiple regression, subspecies $(0=$ toyamensis, $1=$ babai + constricticollis) were included as an independent variable.

\section{DNA sequencing and phylogenetic analysis}

To determine the genetic relationship among the subspecies, partial sequences of the nuclear 28S rRNA gene (28S) were analyzed. A total of 20 ethanol-fixed specimens from 20 localities were used. In addition, samples of the four other Japanese Plateumaris species were used: $P$. weisei $(n=1$ from Higashikawa, Hokkaido), $P$. akiensis ( $n=1$ from Geihoku, Hiroshima), $P$. sericea $(n=1$ from Shimane) and P. shirahatai $(n=1$ from Iwaizumi, Iwate).

Total genomic DNA was extracted from muscles using an AquaPure Genomic DNA Kit (Bio-Rad Laboratories, Hercules, CA, USA). An 804-bp fragment of $28 \mathrm{~S}$ was PCR-amplified using the primer pair 28S-01/28SR-01 (Kim et al., 2000). For direct sequencing of the PCR products, a dye terminator cyclesequencing reaction was performed using an ABI PRISM BigDye Terminator Cycle Sequencing FS Ready Reaction Kit, followed by electrophoresis on an ABI 377 sequencer (Applied Biosystems, Foster City, CA, USA).

Sequence alignment was done manually without gaps. A maximum-likelihood tree was obtained using PHYML version 2.4.4 (Guindon \& Gascuel, 2003) with a GTR $+\mathrm{I}+\mathrm{G}$ substitution model. Node support was obtained using 1000 replicates of nonparametric bootstrapping. A statistical parsimony network was 


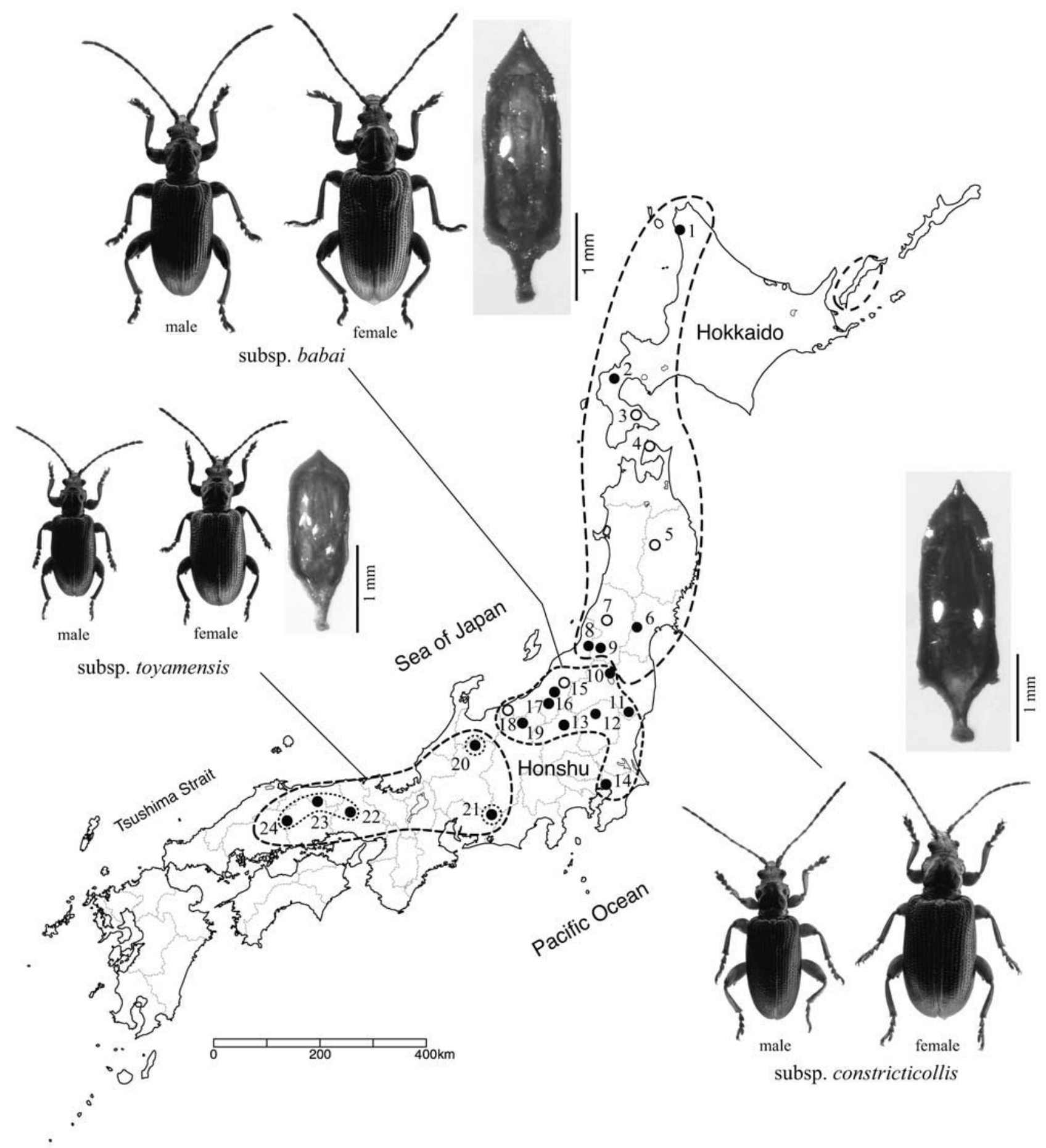

Fig. 1. Sampling localities of Plateumaris constricticollis (closed and open circles). Open circles represent localities where DNA samples only were collected. See Table 1 for locality numbers beside the circles. Photographs are of adult beetles and the ovipositors of three subspecies.

constructed using TCS version 1.21 (Clement et al., 2000) and a $95 \%$ parsimony connection limit.

\section{RESULTS}

The elytral length (EL) and pronotum width (PW) differed among subspecies (nested ANOVA; Table 2 a), and were smaller for subspecies toyamensis than for the other two subspecies (least-squares means \pm standard error [SE], in $\mathrm{mm}$; $\log _{10}$-transformed EL: ssp. babai, $0.81 \pm$
0.0026 ; ssp. constricticollis, $0.80 \pm 0.0032$; ssp. toyamensis, $0.74 \pm 0.0038$; $\log _{10}$-transformed PW: ssp. babai, 0.34 \pm 0.0029 ; ssp. constricticollis, $0.33 \pm 0.0035 ;$ ssp. toyamensis, $0.27 \pm 0.0041)$. The geographical clines of mean EL (Fig. 3a, b) and PW with latitude or latitude were not simple. Both size dimensions had positive coefficients for longitude, but not for latitude (multiple regression; EL: latitude effect, $\mathrm{df}=1, F=0.3, P=0.587$; longitude effect, $\mathrm{df}=1, F=6.2, P=0.024$; PW: latitude 


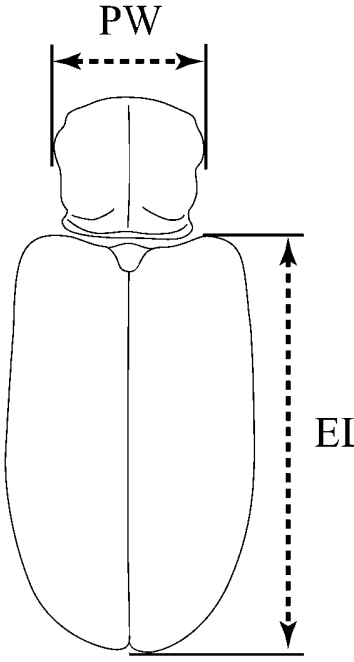

(a)

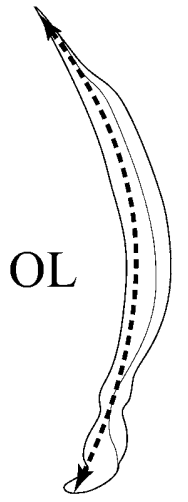

(b)
Fig. 2. Measurements of body size dimensions (a: pronotum width, PW; right elytral length, EL) and ovipositor size dimensions (b: length in lateral view, OL; width in dorsal view, OW).

effect, $\mathrm{df}=1, F=0.2, P=0.633$; longitude effect, $\mathrm{df}=1$, $F=7.0, P=0.0167)$. These size dimensions increased with latitude from about $35^{\circ} \mathrm{N}$ to $37^{\circ} \mathrm{N}$, and were relatively constant between $37^{\circ} \mathrm{N}$ and $45^{\circ} \mathrm{N}$; body size was regressed significantly on latitude when the northern subspecies constricticollis populations were excluded (EL: $\mathrm{df}$ $=11, F=43.7, P<0.0001 ; \mathrm{PW}: \mathrm{df}=11, F=55.6, P<$ $0.0001)$.

Both ovipositor length (OL) and width (OW) were correlated with body size (OL-EL: $r^{2}=0.86$; OL-PW: $r^{2}=$ 0.85; OW-EL, $r^{2}=0.79$; OW-PW: $r^{2}=0.84$; all $P<$ 0.0001 ; Fig. $4 \mathrm{a}$ ). Both OL and OW differed among sub- species (nested ANCOVA; Table $2 \mathrm{~b}, \mathrm{c}$ ). The populationmean OL was correlated with mean EL (and PW). The interaction effect of EL and subspecies was not significant (ANOVA; $P>0.05$ ). After removing the interaction term, subspecies had a significant effect on OL (ANCOVA; EL effect: $\mathrm{df}=1, F=41.7, P<0.0001$; subspecies effect: $\mathrm{df}=2, F=12.0, P=0.0007)$. OL was much shorter in subspecies toyamensis (least square mean $\pm \mathrm{SE}$ of $\left.\log _{10}[\mathrm{OL} \times 10, \mathrm{~mm}]: 1.47 \pm 0.013\right)$ than in subspecies babai $(1.55 \pm 0.008)$ and subspecies constricticollis $(1.54 \pm 0.008)$.

The population-mean OW was correlated with mean OL (Fig. 4b). The interaction effect of OL and subspecies was not significant (ANOVA; $P>0.05$ ). After removing the interaction term, subspecies did not have a significant effect on OW (ANCOVA; OL effect: $\mathrm{df}=1, F=29.1, P$ $<0.0001$; subspecies effect: $\mathrm{df}=2, F=3.4, P=0.0598)$.

Stepwise multiple regression analysis of body and ovipositor dimensions with three climatic variables commonly resulted in models with maximum depth of snow in February, together with the effect of subspecies difference (toyamensis vs. babai + constricticollis) in body size and ovipositor dimensions (Table 3). Only for OL was a model selected that included rainfall, but the effect of rainfall was not significant. Body and ovipositor size increased with depth of snow (Fig. 3c, d).

The 28S sequences were aligned unambiguously without requiring gaps. The $28 \mathrm{~S}$ haplotype (sequence) was monomorphic within subspecies constricticollis $(n=$ 7) and subspecies babai $(n=8)$, but four haplotypes were found for subspecies toyamensis $(n=5$; Fig. 5$)$. The statistical parsimony network revealed that the haplotypes from different subspecies were connected via missing haplotypes. In particular, subspecies constricticollis was separated by three or more steps from subspecies babai

TABLE 2. Nested analysis of variances for the female body and ovipositor sizes.

(a) Elytral length (EL) and pronotum width (PW)

\begin{tabular}{|c|c|c|c|c|}
\hline \multirow{2}{*}{$\begin{array}{l}\text { Dependent variable: } \\
\text { Source variable }\end{array}$} & \multicolumn{2}{|c|}{$\log _{10} E L$} & \multicolumn{2}{|c|}{$\log _{10} \mathrm{PW}$} \\
\hline & $\mathrm{df}$ & $F$ & $\mathrm{df}$ & $F$ \\
\hline Locality (subspecies) & 17 & $18.5 * * *$ & 17 & $16.3 * * *$ \\
\hline Subspecies & 2 & $141.1 * * *$ & 2 & $114.5^{* * *}$ \\
\hline
\end{tabular}

(b) Ovipositor length (OL) and width (OW)

\begin{tabular}{|c|c|c|c|c|}
\hline \multirow{2}{*}{$\begin{array}{l}\text { Dependent variable: } \\
\text { Source variable }\end{array}$} & \multicolumn{2}{|c|}{$\log _{10} \mathrm{OL}$} & \multicolumn{2}{|c|}{$\log _{10} \mathrm{OW}$} \\
\hline & df & $F$ & df & $F$ \\
\hline $\log _{10} E L$ & 1 & $110.5^{* * *}$ & 1 & $129.7 * * *$ \\
\hline Locality (subspecies) & 17 & $14.0 * * *$ & 17 & $13.1 * * *$ \\
\hline Subspecies & 2 & $305.1 * * *$ & 2 & $8.7^{* * *}$ \\
\hline
\end{tabular}

(c) Ovipositor length (OL) and width (OW)

\begin{tabular}{|c|c|c|c|c|}
\hline \multirow{2}{*}{$\begin{array}{l}\text { Dependent variable: } \\
\text { Source variable }\end{array}$} & \multicolumn{2}{|c|}{$\log _{10} \mathrm{OL}$} & \multicolumn{2}{|c|}{$\log _{10} \mathrm{OW}$} \\
\hline & df & $F$ & df & $F$ \\
\hline $\log _{10} \mathrm{PW}$ & 1 & $83.8 * * *$ & 1 & $129.9 * * *$ \\
\hline Locality (subspecies) & 17 & $13.8^{* * *}$ & 17 & $11.0 * * *$ \\
\hline Subspecies & 2 & $266.8 * * *$ & 2 & $12.6 * * *$ \\
\hline
\end{tabular}

$* * *, P<0.0001$. 
(a)

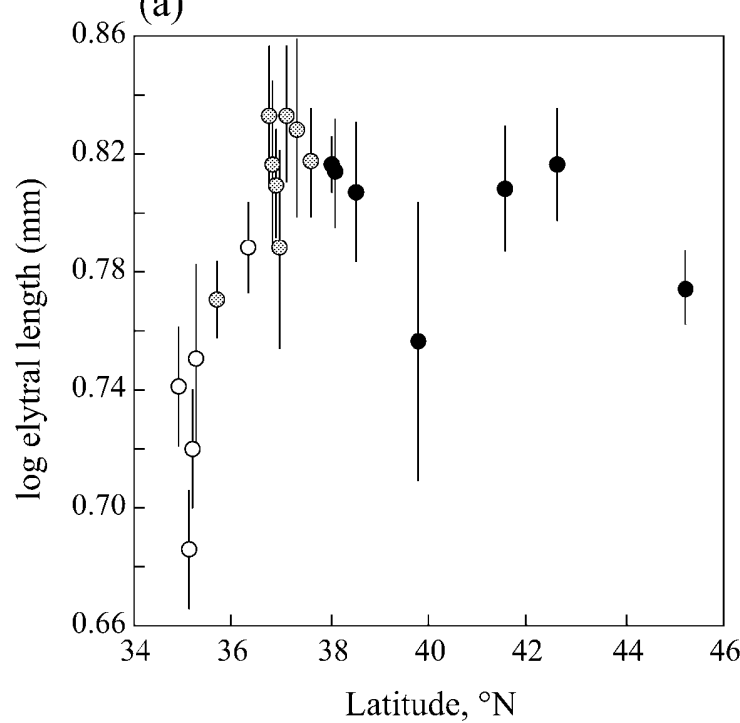

(c)

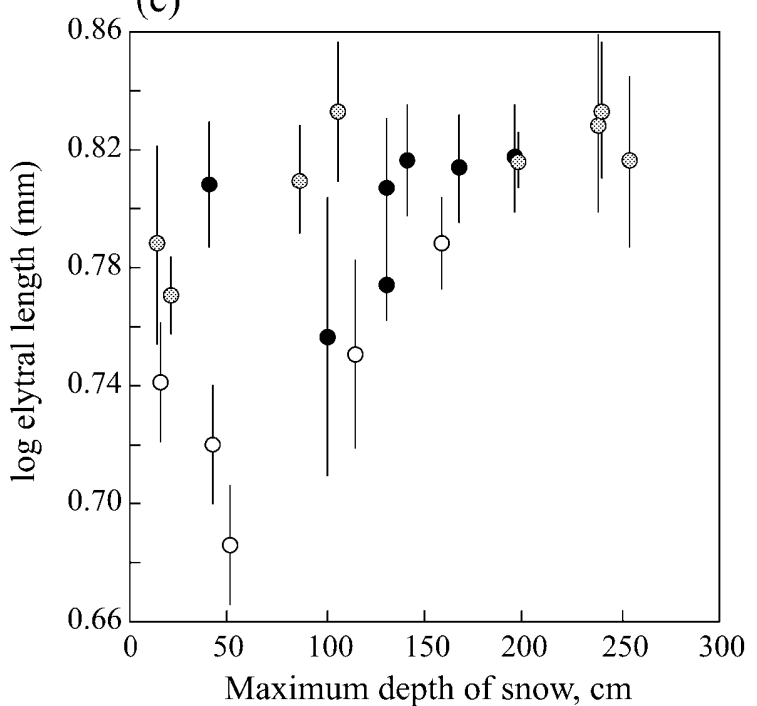

(b)

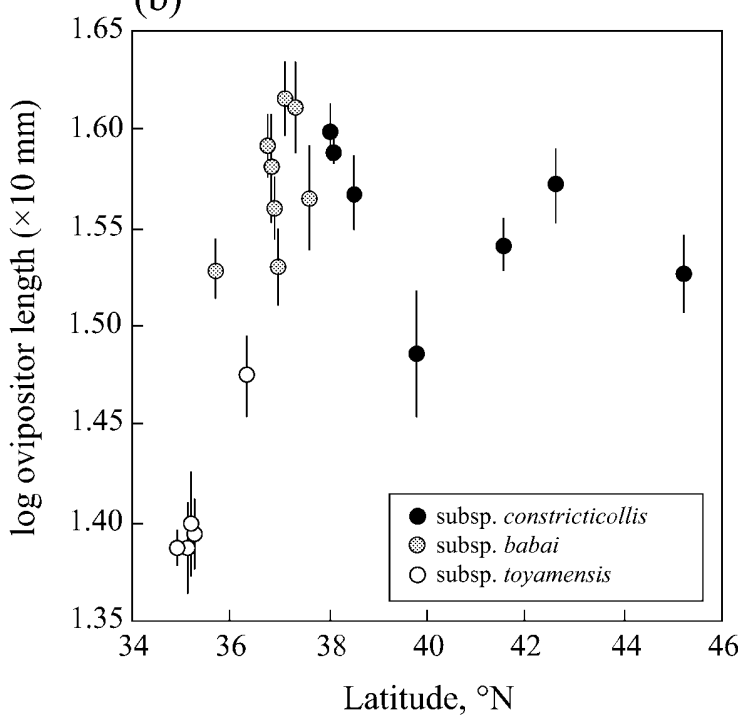

(d)

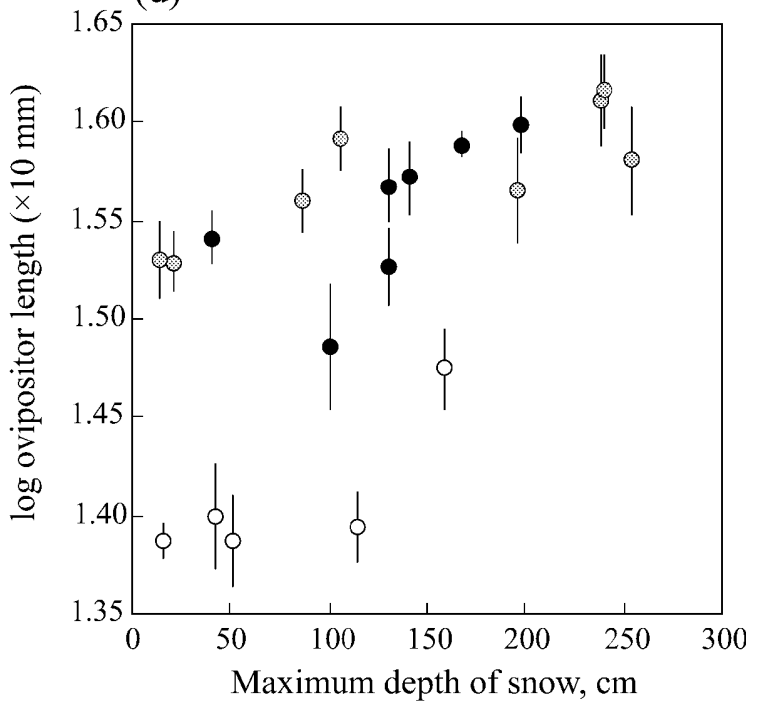

Fig. 3. Variation in elytral length $(\mathrm{a}, \mathrm{c})$ and ovipositor length $(\mathrm{b}, \mathrm{d})$ among local populations of Plateumaris constricticollis, relative to latitude $(a, b)$ and maximum depth of snow in February $(c, d)$. Values are mean \pm SD.

and toyamensis, indicating a deep coalescence between these subspecies.

\section{DISCUSSION}

The three subspecies of $P$. constricticollis were distinguished by their nuclear $28 \mathrm{~S}$ haplotypes. The $28 \mathrm{~S}$ sequence was monotypic for both constricticollis and babai subspecies, whereas four distinct haplotypes were found for toyamensis. Although the sample size was small, the $28 \mathrm{~S}$ gene sequences generally showed very little variation within or between populations. Indeed, the sequences of $P$. weisei, $P$. sericea and $P$. shirahatai are shared by continental populations of the same species $(\mathrm{T}$. Sota, unpubl. data). Thus, differentiation among the subspecies of $P$. constricticollis has a substantial historical basis. Subspecies constricticollis exhibited a rather large genetic differentiation from subspecies babai, despite their small morphological differences (body colour), indicating a long period of differentiation between the two subspecies without strong divergent selection on morphology. The monotypic haplotypes of these subspecies may be attributed to bottleneck events following range contraction. In contrast, the toyamensis subspecies exhibited haplotype divergence among localities, suggesting the relatively long persistence of segregated local populations. A more detailed analysis of $P$. constricticollis's historical biogeography using mitochondrial cytochrome oxidase subunit I gene sequences will be reported elsewhere (Sota \& Hayashi, unpblished data).

Fossils of $P$. constricticollis are recorded from the late Pliocene to the late Pleistocene (e.g., Fossil Insect Research Group for Nojiri-ko Excavation, 1987, 1990; Hayashi, 1999a, b, 2004b) and provide insight into the evolution of body size in subspecies babai. The ovi- 
(a)

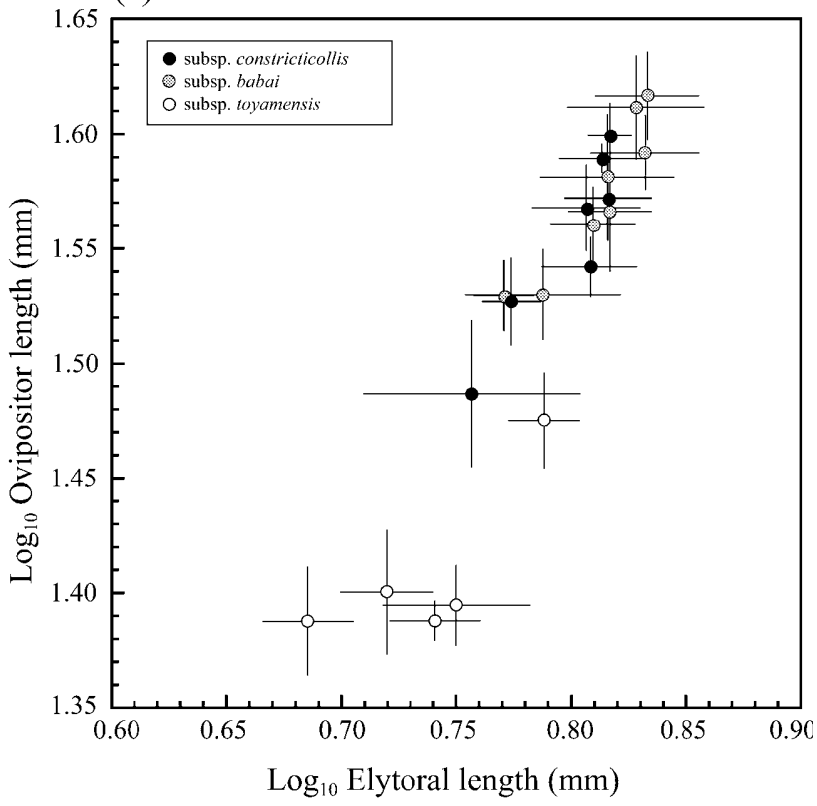

(b)

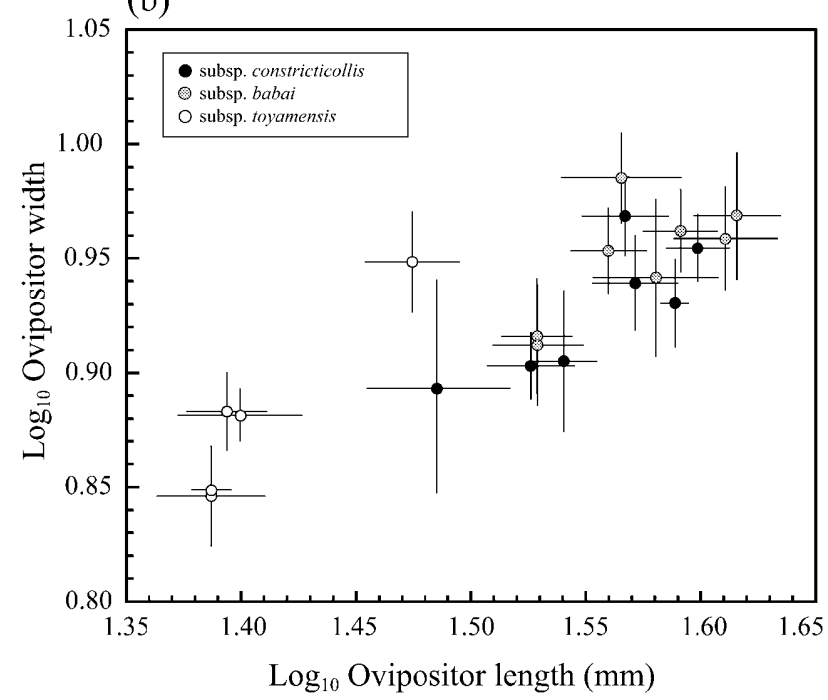

Fig. 4. Relationship between ovipositor length and elytral length (a), and between ovipositor width and ovipositor length (b) in Plateumaris constricticollis. Values are population mean \pm SD. positor shape of early Pleistocene fossils of $P$. constricticollis from the Uonuma Formation in Niigata, Honshu (within the present distribution of subspecies babai) is similar to that of the current subspecies babai, but the body size is small like that of subspecies toyamensis, suggesting that the ancestral body size of subspecies babai may have been smaller than it is today (Hayashi, 1999a). Similarly, P. constricticollis fossils obtained from PlioPleistocene strata in Saitama resemble subspecies babai and constricticollis, but the body size is smaller than in the present subspecies babai (Hayashi, 1999b). In addition, fossils of $P$. constricticollis found in strata from the last glacial period at Nojiriko, Nagano, Honshu, identified as subspecies babai, are smaller than beetles in a nearby extant population, suggesting an increase in body size during the postglacial period (Fossil Insect Research Group for Nojiri-ko Excavation 1987, 1990). Thus, the body sizes of subspecies babai and constricticollis may have changed along with climatic changes. Fossils identified as subspecies toyamensis, based on ovipositor shape and external morphology, occur in the mid-Pleistocene (0.3 Ma) deposits in Gifu, central Honshu (Ego et al., 1988); the body size of these fossils is comparable to the extant toyamensis in the same region, indicating there has not been a body size change in this subspecies.

The body size of $P$. constricticollis did not show simple clinal variation, as is expected based on local adaptation to temperature conditions and a fixed life cycle (voltinism; Masaki, 1967; Roff, 1980). Because Tominaga (1988) mentioned the possibility of selection for large body size in areas with deep snow (see also Ego et al., 1988), we tested the effect of climatic factors, including temperature, rainfall, and snowfall, on body and ovipositor dimensions, and found that only depth of snow had a consistent positive effect on these dimensions. Heavy snowfall in the central northern region of Honshu, facing the Sea of Japan, is associated with the inflow of the warm Tsushima Current from the western Tsushima Channel. The Tsushima Channel was closed until the beginning of the Pleistocene and has been open since, except during glacial periods (Kitamura et al., 2001; Kitamura \& Kimoto, 2004). The correlation of body size with snowfall and the probable change in snowfall pattern after

TABLE 3. Model selected by the stepwise multiple regression analysis. Explanatory variables were annual mean temperature, mean annual rainfall, maximum depth of snow in February and subspecies $(0=$ toyamensis; $1=$ babai + constricticollis $)$.

\begin{tabular}{|c|c|c|c|c|}
\hline Dependent variable $^{a}$ & $\log E L$ & $\log \mathrm{PW}$ & $\log \mathrm{OL}$ & $\log \mathrm{OW}$ \\
\hline \multicolumn{5}{|l|}{ Model } \\
\hline$R^{2}$ & 0.72 & 0.68 & 0.91 & 0.65 \\
\hline $\mathrm{df}$ & 2 & 2 & 3 & 2 \\
\hline$F$ & $21.8^{* * *}$ & $17.8^{* * *}$ & $53.8^{* * *}$ & $15.6^{* * *}$ \\
\hline
\end{tabular}

Regression coefficient:

Independent variable

$\begin{array}{lcccc}\text { Subspecies }(\mathrm{df}=1) & -0.028^{* * *} & -0.028^{* * *} & -0.074 * * * & -0.021^{* *} \\ \text { Snowfall }(\mathrm{df}=1) & 2.1 \times 10^{-4 *} & 2.0 \times 10^{-4 * *} & 2.6 \times 10^{-4 *} & 2.7 \times 10^{-4 * *} \\ \text { Rainfall }(\mathrm{df}=1) & - & - & 1.9 \times 10^{-5} \mathrm{NS} & -\end{array}$

${ }^{a}$ EL - elytral length; PW - pronotum width; OL - ovipositor length; OW - ovipositor width NS, $P>0.05 ;{ }^{*}, P<0.05 ; * *, P<0.01$; $* * *, P<0.001$. 


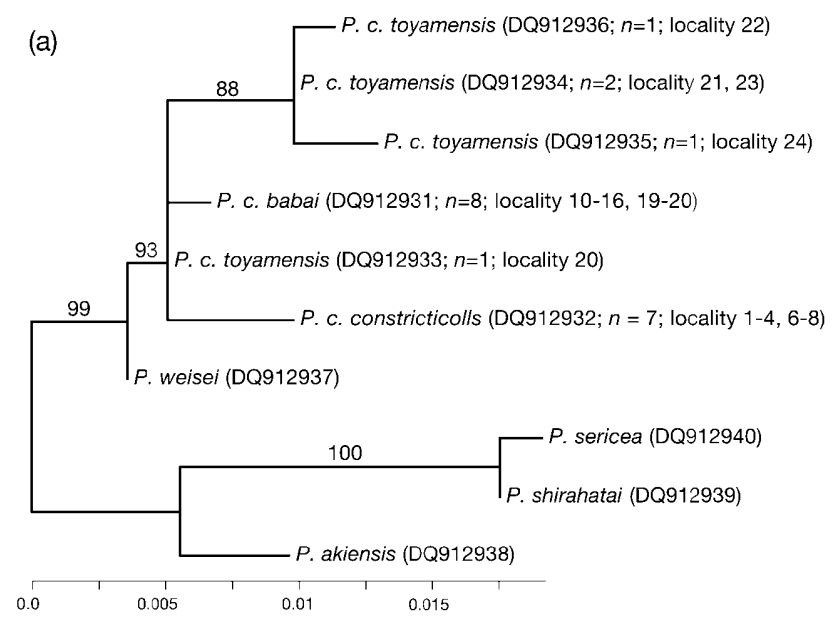

(b)

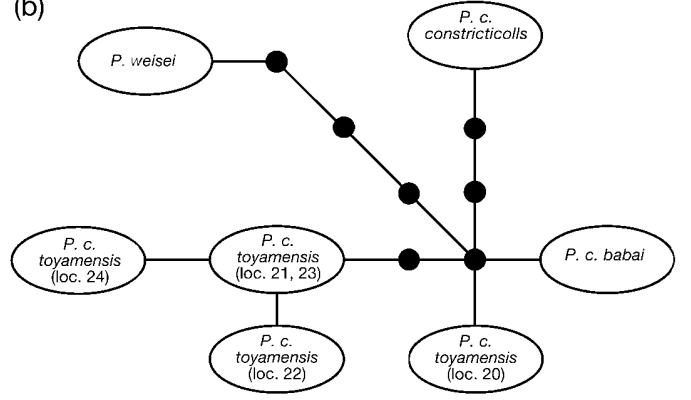

Fig. 5. Phylogram resulting from a maximum-likelihood analysis of the nuclear 28S rRNA gene (upper) and a statistical parsimony network for the same sequence data (lower). GenBank accession numbers for the sequence data are shown in the upper panel.

the early Pleistocene may explain the aforementioned change in the body size of $P$. constricticollis detected by comparing fossil and extant specimens. Thus, with the inflow of the Tsushima Current, the body size of $P$. constricticollis in the north, on the Sea of Japan, would have increased in response to changes in habitat conditions due to heavy snowfall.

The differences in body and ovipositor sizes among the subspecies can be associated with differences in lifehistory traits. The two northern subspecies, constricticollis and babai, emerge as adults in June and early July. The adult beetles mate on Carex spp. and other plants, but have never been observed feeding. Therefore, females are thought to deposit eggs immediately after emergence and mating, without feeding (Fossil Insect Research Group for the Nojiriko Excavation, 1985). In contrast, adult beetles of subspecies toyamensis emerge in late May and June, and feed on pollen and leaves of Carex and Scirpus spp. Ego et al. (1988) and Tominaga (1988) hypothesized an association between large body size and a climate with heavy snowfall, and suspected that the longer larval period under snow cover results in delayed adult emergence and asynchrony with host plant phenology, favouring both the enlargement of body size and gonad maturation without adult feeding. In the region occupied by subspecies toyamensis, the relatively mild climate allows for a short larval period, and natural selection may favour early adult emergence at a smaller body size and active feeding for gonad maturation. In the region of subspecies babai and constricticollis, however, the cool climate would delay larval development and the start of adult activity, and selection would favour adult emergence at a larger size and immediate oviposition without feeding.

Although ovipositor length largely depended on body size, the difference in ovipositor shape between subspecies toyamensis and constricticollis-babai can be related to differences in their host plants. Some of the larval host plants of $P$. constricticollis are known: Carex sp. for subspecies constricticollis (Narita, 2003); Carex thunbergii, Carex ampliata and Phragmites australis for subspecies babai (Hayashi, 2002a; Narita, 2003); and Carex sp. and Eleocharis sp. for subspecies toyamensis [Narita, 2003; Hayashi, 2005; Narita (2003) records Scirpus sp., but it was actually Eleocharis sp.; Y. Narita, pers. comm.]. At some of the locations where subspecies constricticollis and babai were collected, only reeds of Phragmites australis were available and likely to be the sole host plant (Table 1). Ovipositor morphology may represent an adaptation to different host plants because the importance of matching ovipositor length and host plant stem diameter is indicated by laboratory observations (T. Yagi, unpubl. data). Females of subspecies toyamensis with short ovipositors laid eggs in the thin stems of Eleocharis and Carex, whereas females of subspecies babai from Niigata and Nagano, which have long ovipositors, could not use these hosts and laid eggs in the thick stems of reeds. Interestingly, the long ovipositor of subspecies babai went through the stem of Eleocharis and the eggs were laid on the outside of the stem. Because reeds are more common in the habitats of subspecies babai and constricticollis than in the habitats of toyamensis (Table 1), the elongated ovipositor in the former subspecies may an adaptation allowing the use of this plant.

In conclusion, the differentiation in body size and ovipositor size and shape among the subspecies of $P$. constricticollis can be attributed to differential adaptation to host plant and climatic conditions. However, the evolutionary processes remain to be explored further, based on the subspecies' life histories in the field. In particular, more information is needed on host plant use and the life cycle, especially during the larval period.

ACKNOWLEDGEMENTS. We thank K. Katsura and Y. Nagahata for samples, and Y. Narita for information on host plants. Thanks are also due to anonymous reviewers for their helpful comments. Supported by Grants-in-Aid from Japan Society for the Promotion of Science (No. 17405007) and from Ministry of Education, Culture, Sports, Science and Technology, Japan (21st Century COE Research A14).

\section{REFERENCES}

BlANCKENHORN W.U. \& FAIRBAIRN D.J. 1995: Life history adaptation along a latitudinal cline in the water strider Aquarius remigis (Heteroptera: Gerridae). J. Evol. Biol. 8: 21-41. 
Bradford M.J., Guerette P.A. \& RofF D.A. 1993: Testing hypotheses of adaptive variation in cricket ovipositor length. Oecologia 93: 263-267.

Clement M., Posada D. \& Crandall K.A. 2000: TCS, a computer program to estimate gene genealogies. Mol. Ecol. 9: $1657-1660$.

Ego M., Katsura K., Kanazawa I., Kinugasa N., Tominaga O., Harusawa K., Hosoi T. \& Miyatake Y. 1988: Distribuion process and phylogeny of donaciine beetles inferred from fossil data. In Sato M. (ed.): Japanes Beetles, Their Origin and Speciaiton. Tokai University Press, Tokyo, pp. 165-179.

Fossil Insect Research Group for the NoJiriko Excavation 1985: Atlas of the Japanese Donaciinae: Guide for Identification of the Fossil Donaciine Beetles. Fossil Insect Research Group for the Nojiriko Excavation, Osaka, 182 pp. [in Japanese].

Fossil Insect Research Group for the NoJiri-Ko Excavation 1987: Fossil insects obtained from the Nojiri-ko Formation in the 9th Nojiri-ko excavation and the 4th hill site excavation. Monograph Assoc. Geol. Collab. Japan 37: 93-110 [in Japanese].

Fossil Insect Research Group for the NoJiri-ko Excavation 1990: Fossil insects obtained from the Nojiri-ko Formation during the 10th Nojiri-ko and the 5th hill site excavation. Monograph Assoc. Geol. Collab. Japan 32: 117-136 [in Japanese].

Guindon S. \& Gascuel O. 2003: A simple, fast, and accurate algorithm to estimate large phylogenies by maximum likelihood. Syst. Biol. 52: 696-704.

HaYAShi M. 1999a: Late Pliocene to Early Pleistocene donaciinae fossils from the Uonuma Formation in Higashikubiki hills, Niigata Prefecture, Japan, with description of a new species (Coleoptera: Chrysomelidae: Donaciinae). Bull. Osaka Mus. Nat. Hist. 53: 1-22.

HAYASH M. 1999b: A revisional study on fossil Donaciinae from the Plio-Pleistocene Kazusa Group in Saitama Prefecture, Japan, with reference to phylogeny of the extinct Plateumaris dorsata Hayashi (Coleoptera, Chrysomelidae). Earth Sci. 53: 38-52.

Hayashi M. 2002a: Host plants of Plateumaris constricticollis babai Chûjô (Coleoptera: Chrysomelidae: Donaciinae). Entomol. Rev. Japan 57: 203-204.

HAyashi M. 2002b: Late Cenozoic Coleoptera of Japan (Part 4): Donaciinae. Gekkan-Mushi 374: 36-38 [in Japanese].

HAYASHI M. 2004a: Revisional study on Japanese members of Donaciinae (Coleoptera: Chrysomelidae). Bull. Hoshizaki Green Foundation 7: 29-126.

HaYAshi M. 2004b: Faunal changes in Donaciinae during the Quaternary in central Japan (Coleoptera, Chrysomelidae). In Jolivet P., Santiago-Blay J.A. \& Schmitt M. (eds): New Development in the Biology of Chrysomelidae. SPB Academic Publishing, The Hague, pp. 263-274.

HAYASHI M. 2005: Illustrated manual of Japanese Donaciinae. Gekkan-mushi 408: 2-18.

Hayashi M. \& ShiYake S. 2002: Late Pliocene Donaciinae (Coleoptera, Chrysomelidae) from the Koka Formation, Kobiwako Group in Shiga Prefecture, Japan. Elytra (Tokyo) 30: 207-213.
Hayashi M. \& Shiyake S. 2004: A check-list of the Japanese members of Donaciinae (Coleoptera: Chrysomelidae). Entomol. Rev. Japan 59: 113-125.

Kim C.G., Zhou H.Z., Imura Y., Tominaga O., Su Z.H. \& OsaWA S. 2000: Pattern of morphological diversification in the the Leptocarabus ground beetles Coleoptera, Carabidae as deduced from mitochondrial ND5 gene and nuclear $28 \mathrm{~S}$ rDNA sequences. Mol. Biol. Ecol. 17: 137-145.

Japan Meteorological Agency 2002: Mesh Climatic Data 2000. Japan Meteorological business support center, Tokyo.

Kitamura A. \& Кiмото K. 2004: Reconstruction of the southern channel of the Japan Sea at 3.9-1.0 Ma. Quat. Res. (Daiyonki-Kenkyu) 43: 417-434 [in Japanese with English abstr.].

Kitamura A., Takano O., Takata H. \& Omote H. 2001: Late Pliocene-early Pleistocene paleoceanographic evolution of the Sea of Japan. Palaeogeogr. Palaeoclimatol. Palaeoecol. 172: 81-98

MASAKI S. 1967: Geographic variation and climatic adaptation in a field cricket (Orthoptera: Gryllidae). Evolution 21: 725-741.

MASAKI S. 1978: Climatic adaptation and species status in the lawn ground crickets. II. Body size. Oecologia 35 : 343-356.

MASAKI S 1979: Climatic adaptation and species status in the lawn ground crickets. III. Ovipositor length. Oecologia 43: 207-219.

MASAKI S 1986: Significance of ovipositor length in life cycle adaptations of insects. In Taylor F. \& Karban R. (eds): Insect Life Cycles. Springer, Berlin, pp. 20-34.

MousseAu T.A. \& RofF D.A. 1989: Adaptation to seasonality in a cricket: patters of phenotypic and genotypic variation in body size and diapuse expression along a cline in season length. Evolution 43: 1483-1496.

Mousseau T.A. \& RofF D.A. 1995: Genetic and environmental contributions to geographic variation in the ovipositor length of a cricket. Ecology 76: 1473-1382.

NARITA Y. 2003. Descriptions of Donaciinae larvae (Coleoptera, Chrysomelidae) from Japan. Elytra (Tokyo) 31: 1-30.

RofF D.A. 1980: Optimizing development time in a seasonal environment: the "ups and downs" of clinal variation. Oecologia 45: 202-208.

Sota T., Takami Y., Kubota K. \& IshiKawa R. 2000a: Geographic variation in the body size of some Japanese Leptocarabus species (Coleoptera, Carabidae): The "toppled-domino pattern" in species along a geographic cline. Entomol. Sci. 3: 309-320.

Sota T., Takami Y., Kubota K., Unie M. \& Ishikawa R. 2000b: Interspecific body size differentiation in species assemblages of the carabid subgenus Ohomopterus in Japan. Popul. Ecol. 42: 279-291.

Толч H. \& Sота T. 2006a: Imbalance of predator and prey armament: geographic clines in phenotypic interface and natural selection. Am. Nat. 167: 105-117.

Toлu H. \& SотA T. 2006b: Phylogeography and the geographical cline in the armament of a seed-predatory weevil: effects of historical events vs. natural selection from the host plant. Mol. Ecol. 15: 4161-4173.

Tominaga O. 1988: When did Plateumaris constricticollis babai become large? Tohoku-no-shizen 41: 5-7 [in Japanese].

Received September 1, 2006; revised and accepted October 27, 2006 